\title{
THE DEPARTMENT OF SCIENTIFIC AND INDUSTRIAL RESEARCH
}

\author{
REPORT FOR 1955-56
}

$\mathrm{T}$ HE annual report of the Department of Scientific and Industrial Research for the year 1955-56* includes the report of the Committee of the Privy Council for the year ended September 30, 1956, over Lord Home's signature, and the forty-first, and last, report of the Advisory Council, signed by Sir Harry Jephcott, which includes the customary summary of work carried out by the various research stations and boards and research associations. Besides the summary of the Department's expenditure for the year ended March 31, 1956, there are appended a copy of the Department of Scientific and Industrial Research Act, 1956, under which the present Advisory Council is replaced by an Executive Council, lists of assessors to the Advisory Council, of the various committees of the Advisory Council and their membership, of tho research boards and establishments of the Department, of grants for spocial researches in progress or authorized during the year, of students awarded maintenance allowances for postgraduate training in research and a 49-page list of publications issued during the year.

The gross expenditure of $£ 7,350,738$ compares with $£ 6,685,400$ in tho previous year and is reduced to $£ 6,428,693$ by various receipts ( $£ 407,222$ being from the National Physical Laboratory) for work done for government departments or for industry, the net

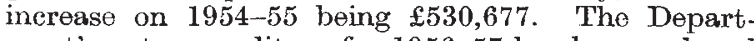
ment's net expenditure for $1956-57$ has been reduced by about $£ 150,000$ as part of the Government's economy campaign, and although the effect of this reduction will be to slow down rather than stop the Department's programme of planned expansion and development, it is deplored by the Advisory Council. Moreover, two building projocts-an experimental road system, designed as the first part of a new Road Research Laboratory, and a new chemistry building at the Building Research Station-on which work was to have started in 1956-57 have been deferred, and the Advisory Council urges very strongly the importance of an early resumption in full of the Department's building plans. On October 1, 1956, the Department employed 4,655 staff of all grades (including 200 part-time), compared with 4,379 (190 part-time) in the previous year, and as a result of this increase the deficioncies which had accumulated during the two preceding years have largely been overtaken. Annual grants to research associations totalled $£ 1,423,775$ (compared with $£ 1,335,125$ in $1954-55$ ), grants for special researches amounting to $£ 373,028$ ( $£ 315,425$ in $1954-55)$. Grants to students amounted to $\mathfrak{1 3 1 9 , 9 1 9}$, a decrease of $£ 3,103$, the number of students in training in 1955 being 1,012 , and in $1956,1,006$, and of these, 379 in 1955 and 404 in 1956 were new. Of eight senior research awards in 1955 and seven in 1956, five in 1955 and four in 1956 were new, and 15 new grants for special researches in 1954 and 46 in 1955 brought tho total of such grants to 53 and 99, respectively, compared with 58 in 1953 and 64 in 1954. Of the grants for special researches, 33 in 1955 and 54 in

* Department of Scientific and Industrial Research. Report for the year 1955-56. Pp. 314. (Cmnd, 213.) (London: H.M. Stationery Office, 1957.) 9s. $6 \dot{d}$. net.
1956 were in physics ; for chemistry, the figures were 9 and 14 ; for biology, 4 and 7 ; for engineering, 4 and 5 ; for mathematics and astronomy, 1 and 7 ; and for geology and mineralogy, 1 and 8 . In 1955 chemistry claimed 399 , and in 1956372 , of the students receiving grants; in physics the corresponding figures were 262 and 256 ; in biology, 107 and 108 ; in mathematies and astronomy, 86 and 96 ; in engineering, 91 and 42 ; in geology and mineralogy, 42 and 43 ; and in chemical engineering and metallurgy, 23 and 58.

Expenditure on the National Physical Laboratory of $£ 946,890$ gross or $£ 542,668$ net was slightly less than in 1954-55 (£556,435), and there were also decreases in the expenditure on food investigation (from $£ 373,208$ to $£ 358,528$ net), radio research (from $£ 107,298$ to $£ 104,119$ net) and forest products research ( $£ 116,487$ to $£ 116,161)$; but expenditure on the other branches of the Department's activities increased, the largest increase being in the expenditure on mechanical engineering research (from $£ 315,561$ to $£ 436,006$ ). Net expenditure under the other major headings in 1955-56 was as follows, the increase over 1954-55 being given in brackets : building research, $£ 492,701(£ 39,652)$; road research, $£ 388,436$ ( $£ 44,920)$; fuel research, $£ 288,260$ ( $£ 17,841)$; Geological Survey and Museum, $£ 268,046$ ( $£ 44,636)$; Chemical Research Laboratory, $£ 139,226(£ 2,876)$; hydraulics research, $£ 84,046(£ 7,877)$; water pollution research, $£ 76,482$ $(£ 2,161)$; pest infestation, $£ 72,284(£ 4,139)$; fire research, $£ 31,781(£ 9,348)$; headquarters, administration, etc., £272,581 (£24,636), and headquarters, overseas liaison, etc., $£ 76,235$ ( $£ 5,797$ ).

The contribution to the European Organization for Nuclear Research also increased from $£ 359,787$ to $£ 519,996$, and while only some $£ 40,000$ out of the expenditure of $£ 315,425$ net on grants for special researches authorized in the year ended September 30 , 1956, was for nuclear research, grants totalling

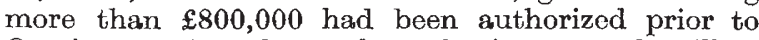
October 1, 1955, for nuclear physics research still in progress, as well as more than $£ 40,000$ for equipment.

Those research stations with the work of which the Advisory Council's report is this year specially concerned are the Road Research Laboratory, the Water Pollution Research Laboratory and the Chemical Research Laboratory, all of which were visited by the Advisory Council. The Advisory Council was particularly impressed with this, its first, visit to the new Water Pollution Research Laboratory at Stevenage, and was satisfied that the work is well planned to achieve results of practical value and that co-operation with 'user' interests is outstandingly good. In particular, the Advisory Council believes that in the survey of the conditions in the Thames, undertaken in co-operation with the Port of London Authority, the work of the Laboratory has pointed the way to a proper understanding, of the greatest economic value, of the effects of the manifold sources of trouble in the river, and of their complicated interactions and seasonal variations. The investigations have made it possible to devise reliable methods of forecasting the effects of a new source of pollution or of a new remedial method, and by so 
doing have provided a quantitative basis for assessing the best and most economical means for dealing with a problem vital to the health and work of Londoners. Other work of the Laboratory has been concerned with the tolerance of different species of British freshwater fish to low concentrations of dissolved oxygen over the range of temperatures to be expected in British rivers.

In the two main sections of the Road Research Laboratory, a little less than two-thirds of the resources are devoted to problems of road construction and a little more than one-third to safety and traffic. The Laboratory's investigations on the possible economic returns from building new roads appear to be of particular interest at present, and it is expected that the new road construction programme will offer greater opportunities for use of a trial method of assessment which has been worked out. The Advisory Council was impressed with the contribution which the Laboratory's work is making to improving the quality and lowering the cost of road construction and pointing the ways to a smoother flow of road traffic and the achievement of greater safety. As particular examples may be mentioned the Laboratory's study of the effectiveness of the various ways of indicating a turn, including flashing indicators and semaphore arms, now in use on vehicles; of the bearing of street lighting on accidents, and on the development of standards of minimum resistance to skidding for different types of roads; its study of the stabilization of soils with a high clay content, of soil compaction, and of testing techniques for rapidly assessing the quality and thickness of the various layers forming a road and for determining the load-spreading characteristics of the road structure.

The Advisory Council was much impressed with the scientific quality of the work of the Chemical Research Laboratory. The Council emphasizes that the Laboratory is intended to undertake chemical research on selected problems of national interest, and on investigations on lines for which no provision exists in the universities or in industrial laboratories. The emphasis on the importance of careful selection of subjects may be of special significance in view of the change in the organization of the Department under the new Act. In further work on the separation of individual rare earths by ion-exchange methods, the Laboratory has found that inproved separations are obtained if the rare earths are diluted with ammonium ions so that they occupy a longer length of the ion-exchange column. Two new instruments have been developed for applying the technique of zone-melting to the separation and precipitation of organic compounds, a new technique has been developed for fractionating high polymers and encouraging progress made in the development of paper-strip chromatography as a micro-mothod for the determination of molecular-weight distributions of polymers.

An investigation by the Building Reserrch Station has shown that savings in water consumption amounting to more than a million gallons a year with a decrease in solid fuel consumption of more than 50 tons could be achieved in a large office building with a staff of more than a thousand by substituting spray taps (supplying blended hot and cold water) for the normal pillar taps used for washing. Other work of the Station has indicated the possibility of reducing the cost of a flat in a block of six stories or more as much as $£ 450$ a flat by combining the economic features of different designs, and research in co-operation with the Midland Regional Board for Industry is endeavouring to provide authoritative data on the most suitable and economic forms of factory design and construction. An investigation into casualties caused by the ignition of clothing, while not yet complete, has indicated the need for increased emphasis on the design of clothing, on the use of fire-guards and on increased care for the young and old, while the textile industry continues its researches on flameretardant treatments.

In food investigations the potential use of antibiotics in the preservation of fresh foods is being studied experimentally, and the small unit of the Low Temperature Research Station at Cambridge has resumed its studies of the use of ionizing radiations to extend the storage life of selected foodstuffs. For this purpose it has been strengthened by staff seconded from the British Food Manufacturing Industries Research Association and from industry. Other investigations are concerned with the serious wastage in the meat industry from the concealed loss of offal and tissues of the carcass when an animal is being taken to an abattoir and rested before slaughter, the reasons for the marked decline in consumption of smoked fish and the development of improved processes for smoking. Use of nonyl alcohol vapour has been found to provide a simple, effective and cheaper method of suppressing the sprouting of potatoes on a pilot-scale up to 15 tons; and further work on the application of refrigeration and the use of carbon dioxide in the transport of soft fruits has made it possible to specify the conditions required for successful pre-cooking of soft fruits and transport from farm to market.

The Forest Products Research Laboratory is devoting increasing attention to the study of homegrown softwoods, and besides developing simpler and more effective methods of bending for industrial use, has attempted to devise a method of impregnating test samples with low concentrations of creosote while ensuring its uniform distribution. In cooperation with the Atomic Energy Research Establishment, the treatment of infested timber with gamma-rays has received much attention. The Fuel Research Station intensified its efforts towards the efficient utilization of the more plentiful coals, including those of small size and comparatively low quality, and the Station also obtained a correlation between mortality and the observed atmospheric pollution in the different districts of London.

A generous financial grant by the Nuffield Foundation for an airborne magnotic survey to allow assessment of the potentialities of the method and study of alternative techniques permitted a survey of about 11,000 sq. miles in the Midlands, and concurrently magnetic measurements were made at about twentyfive ground stations distributed over the whole of Great Britain. A survey of Norfolk showed that only about 5 per cent of the available ground-water resources are being used; a similar survey is being made in south-east Lincolnshire.

The staff of the Mechanical Engineering Research Laboratory increased by 14 per cent during the year, but the general balance of fundamental and applied research was little changed. The special equipment for basic research on the principles underlying the design of hydraulic machinery has been completed with the erection of a closed circuit for cavitation 
research on water-turbines. Much attention is being given to fundamental studies of wear, and a fundamental investigation of the causes of varying adhesion between wheel and rail is being carried out for the British Transport Commission. Two very accurate electric dynamometers have been developed for research on power transmissions, and the Heat Division is attempting to provide more accurate basic design data for conventional and novel types of heat exchanger.

The work of the National Physical Laboratory has recently been reviewed in these columns and no more need be added here than that the Control Mechanisms and Electronics Division is sponsoring the development of auxiliary machinery which would permit the cost of certain clerical tasks to be cut by more than 50 per cent by using types of scientific computer now on the market, and that work in the Ship Division has shown that on the same power output a well painted and a badly painted ship may differ by as much as half a knot in speed. Work on grain storage has shown that quite damp grain, such as may be harvested by combine in a wet season in Britain, can be stored for several months in air-tight metal bins without detriment to use for feeding to stock. 'The new laboratories at the Radio Research Station, where studies on the propagation of radio waves over a very wide band of frequencies absorbed the bulk of the effort in radio communications research, came into use in June 1956. In radio-navigational aids the effort has now been diverted to much lower frequencies which show promise of being suitable for use at longer distances, while in work on semiconductors an appreciation has been obtained of the dependence on frequency of the noise per unit bandwidth developed in monocrystalline filaments of germanium carrying current, and in back-biased, point-contact and junction diodes.

During the year 1955-56, grants were offered to two now research organizations, bringing the total of grant-aided bodies to thirty-nine research associations, seven research councils or committees not yet of research association status, and three other institutions the activitios of which are of special interest to industry. A block grant of $£ 3,000$ a year, conditional on $£ 6,000$ of grant-earning income from the industry with up to an additional $£ 4,000$ on a cent-per-cent basis, was offered to the Heating and Ventilating Research Council for the period January 1, 1956December 31, 1958, to provide a co-operative research organization for an industry with an estimated annual turnover of $£ 35$ million and employing some 12,00013,000 operatives. A grant to the National Institute of Industrial Psychology on the same terms as those governing grants to research associations will make possible sustained studies of general interest, and the grant terms of the Commonwealth Mycological Institute have been modified for the final two years of the current grant period. A special grant was offered to the British Coke Research Association for the erection of a full-scale coke-oven plant, the first in Britain to be available for research.

New terms of grant were offered to eight research associations and research councils during the year. The Printing, Packaging and Allied Trades Research Association will receive for the period April 1, 1956March 31, 1961, a block grant of $£ 27,000$ conditional on $£ 67,500$ coming from industry, with up to $a_{0}$ further $£ 18,000$ on a cent-per-cent basis. A main research project has been an investigation into what constitutes a good print, so that a method of comparison can be evolved. A new damping solution which will minimize the printing of non-image areas without leading to other troubles, and a treatment for preventing damping rollers from rotting have been introduced for lithographers; further progress has been made with the development of a contact screen capable of giving improved tone reproduction in lithography, development work has continued on tests for assessing wear-resistance of book-binding materials, and accurate information is being accumulated on how packages behave in transit as a basis for improved design of containers.

The past year's work of the British Baking Industries Research Association, which, for the period July 1, 1956-June 30, 1957, will receive a block grant of $£ 11,000$, conditional on $£ 20,000$ coming from industry, with up to a further $£ 8,000$ on a cent-percent basis, reflects the influence of technological advances generally on a traditional industry. New techniques in mixing indicate changes in baking methods which may offer more economical production and products of improved quality, while deep freezing of bread, flour confectionery, doughs and batters also offers promising possibilities. Longterm experiments now completed indicate that no loss of vitamin $B_{1}$ occurs during the fermentation of bread dough ; but in baking, 17.3-23.3 per cent of this vitamin is lost and, depending on the thickness of the slice of bread, a further 13.4-31.0 per cent is destroyed during toasting. One of the most important investigations of the British Jute Trade Research Association, the block grant of which has been increased to $£ 16,000$ a year for the period July 1 , 1956-June 30, 1961, provided $£ 27,000$ is received from industry, with up to a further $£ 10,000$ on $\mathbf{a}$ cent-per-cent basis, is concerned with improving the quality of jute yarns as a result of changes in carding procedures. A special softening machine has been developed to provide different types of fireproof finishes on jute cloths using a process developed in the laboratories, and an investigation on minimizing fibre degradation under exposure to sea-water has been largely completed. Basic and fundamental research (about one-fifth of the total effort) has been devoted to elucidating the chemical structure of the jute fibre and the mechanism of chemical reactions which adversely affect fibre properties.

The Research Association of British Paint, Colour and Varnish Manufacturers will receive a block grant of $£ 22,500$ for the period July 1, 1956-June 30, 1961, conditional on $\$ 45,000$ coming from industry and up to a further $£ 12,000$ on a cent-per-cent basis. Radioactive tracer techniques have proved of great value in studies of reaction mechanisms involved in processing drying oils and in the drying of films, while in work on epoxide resins infra-red spectroscopy has been used to follow the basic reactions during curing with amines and polyamides. Methods of assessing the particle-size, shape and distribution and total surface area of pigment powders are being made more effective and reliable, and the crystal structure of pigments has been further investigated; much has been learnt by direct observation of the position of pigment particles in paint films, singly or in clusters and at various depths. A study of spectrophotometric and potentiometric titration of chromate ions in acid solution has led to a method of determining chromates in pigments, and the effects of selected pigments have been closely examined in relation to 
the build-up of films and their breakdown. For the period July 1, 1956-June 30, 1961, the British Rayon Research Association will receive a block grant of $£ 80,000$ a year, conditional on $£ 250,000$ being received from industry, with an additional $£ 50$ for each $£ 100$ contributed by industry up to a maximum of $£ 10,000$. In fundamental research considerable progress has been made in elucidating the precise molecular arrangements in the crystalline forms of cellulose, particularly by using infra-red spectroscopy, while a study of the kinetics of the photochemical breakdown of cellulose in the presence of dyestuffs has established that the activated triplet state of the dye molecule is responsible for the breakdown. The Association has undertaken a programme of work on blended yarns, and finds that there are no outstanding difficulties in spinning, warping and weaving in producing cloths from blends of viscose with acetate rayon, nylon, 'Terylene', 'Orlon', 'Celon' and 'Acrilan'. Application of fluid-bed techniques in textile processing operations, such as drying, dyeing and finishing, appears to offer great potential savings.

For the period April 1, 1956-March 31, 1958, the British Scientific Instrument Research Association will receive a block grant of $£ 40,000$ per annum provided that $£ 25,000$ is received from industry, with up to a further $£ 15,000$ on a cent-per-cent basis. Progress is being made in an important investigation of ceramic elements which are sensitive to humidity, and an improved amplifier has been devised for the millivolt-level. A method of calculating the transmission characteristics of multi-layer interference filters has been developed. The main work of the British Electrical and Allied Industries Research Association, which for the period January 1, 1957December 31, 1958, will receive a block grant of $£ 100,000$ a year, conditional on $£ 200,000$ coming from industry, continues to be concerned with the generation of electrical energy, its economical transmission and distribution, its most efficient utilization and the reliability of equipment, and about 15 per cent of the effort continues to be of long-term fundamental character. The hydrogen-oxygen fuel cell is now ready for industrial development, and new ground has been broken in the study of the interruption of circuits in vacuo. There appear to be promising applications to high- and low-power switchgear, contactors and rectifiers. The use of digital computers has permitted the application of more accurate mathematical methods of calculating short-circuit forces in transformers; laboratory work continued on basic problems of crop drying and the design of farmdryers has been improved. A study of the relation between moisture content and discharge inception in impregnated paper insulation has established a strong correlation between these properties, while the study of ferro-electric materials is now directed to mixed sodium/potassium niobates. The Wool Industries Research Association, which for the period October 1, 1956-September 30, 1958, will receive a block grant of $£ 40,000$ a year, conditional on $£ 110,000$ coming from industry, with up to a further $£ 30,000$ on a cent-per-cent basis, is putting into production a dropper pinning machine, which eliminates much labour in setting up the warp stop motion on automatic looms. The Raper autoleveller drawing system, in the development of which the Association assisted, has proved most successful, offering a 10 per cent saving in labour as well as significant reduction in waste. Work on piece scouring has shown how economies in the use of hot water as well as in scouring-time can be obtained while maintaining or improving the quality of the product, and a more detailed study of fibres containing radioactive cystine showed no differentiation between the ortho- and para-keratins which have been postulated for the two halves of the fibre.

Of the work of the remaining research associations, only a few points can be mentioned here to illustrate further the many-sided bearing of the Department's work on the national life of Britain. The British Boot, Shoe and Allied Trades Research Association has done much practical work on the difficult problems of securing suitable adhesion between the uppers of shoes and newer synthetic solings, and promising and original work has been done at an experimental training centre to develop methods of selecting and training untrained labour for stitching operations in shoe factories. The British Ceramic Research Association has designed a satisfactory hood for the control of dust from the towing process and for dealing with the allied problem of hollowware fettling, as well as studying the effect of rate of drying on strains set up in clay bricks and blocks and the magnitude of the stresses that cause cracking. The British Coal Utilization Research Association has constructed special apparatus, consisting of a model fuel-bed burning beneath an electrostatic precipitator, for measuring the smoking tendency of coals and of manufactured smokeless fuels. The Cutler Research Council has developed a process for bending curved scissor blades that has been almost universally adopted by that section of the trade.

Fundamental data on the nutritive value of the proteins of flour, obtained by the Research Association of British Flour-Millers, indicate that the potential value of wheat protein is only fully mobilized in the presence of relatively small amounts of other proteins which are good sources of lysine. When these conditions are realized, the protein of wheat assists notably in maintaining a high biological value for the mixed proteins in the diet; and, so far as the protein content is concerned, the rate of extraction of the flour then becomes unimportant. The British Food Manufacturing Industries Research Association has extended its study of the increase in 'mould count' of soft fruits during transport and its retardation under improved conditions of transport, and the Fruit and Vegetable Canning and Quick Freezing Research Association is again investigating the chemical and physical changes during the ripening of green peas for canning and freezing. By the use of trypsin digestion in measuring the average molecular weight of fractions of gelatin by the technique of light scattering, the British Gelatine and Glue Research Association has removed the principal uncertainty in this method, the gelatin being degraded in a few minutes to an extent which permits the direct measurement of scatter due to impurities. A major project of the British Glass Industry Research Association is to reach some understanding of the mechanical strength of glass; while the fundamental work of the British Hydromechanics Research Association on the flow of liquid-solid mixtures in pipes has been extended from the behaviour of relatively large particles -of particular interest in connexion with coal transport-to smaller sizes of material. The new continuous casting plant of the British Iron and Steel Research Association promises to give outputs of steel considerably higher than the 
present 7 tons an hour. 'The new method of flameproofing nylon net devised by the Lace Research Association is now being used on almost all nylon net placed on the market by the industry. 'The British Launderers' Research Association has found that 'Polythene' is suitable only for low-temperature washing, but that some 'Terylene' garments will stand processing of the type suitable for white cotton. A dominant feature of the work of the British Leather Manufacturers' Research Association has been the study of methods of producing leathers with specific properties, such as hard wear, water-proofness and flexibility. Investigations by the Motor Industry Research Association point to the possibility of virtually eliminating brake squeal at small cost, and the Association has also sponsored a study of the mechanism of oil consumption by the engine piston and rings. The non-destructive thickness gauge for metallic coatings invented in the British Non-Ferrous Metals Research Association's laboratories has now been developed to measure the thickness of duplex coatings, particularly nickel and copper coatings on steel and on zinc die-castings, while progress is reported in the production of thick uncracked chromium deposits, using conventional plating plant and procedure. Oil-less water-based cutting fluids containing non-proprietary corrosion inhibitors developed by the Production Engineering Research Association have offered important savings to manufacturers of such fluids, and work of the Research Association of British Rubber Manufacturers on the prevention of deterioration due to traces of copper, manganese and iron using sequestering agents has added greatly to our knowledge of these oxidation processes and how these trace metals and sequestering agents work.

\section{SCIENCE IN SCHOOLS}

A SESSION of Section X (Corresponding Societies) of the British Association for the Advancement of Science was held on September 10 in the Great Lecture Theatre of the Science Buildings of University College, Dublin. The audience, which was large, included Prof. P. M. S. Blackett, president of the Association, and Mrs. Blackett ; Dr. Henry St. John Atkins, president of University College, Cork; The Rev. Prof. J. McConnell, of Maynooth ; Dr. A. C. Williams, senior chief inspector of the Ministry of Education of Northern Ireland; Mr. P. McGeown, inspector of the Department of Education in Eire; Prof. J. Doyle, Prof. T. Murphy and Prof. F. Hackett, of University College, Dublin. Prof. D. A. Webb, of Trinity College, Dublin, president of Section X, was in the chair.

The Rev. Dr. M. T. Casey, lecturer in general science at Maynooth College and senior science master at Newbridge, opened the session with an address on "Science in Our Irish Schools". He said that only 60 per cent of the boys and less than 50 per cent of girls take an academic science subject at Leaving Certificate level. In girls' schools generally-with some very notable exceptions-academic science is much neglected. Very few take physics or chemistry. Some take botany, but the majority select physiology and hygiene as a kind of 'soft option'. In the absence of physics and chemistry, this subject loses a great deal of its value. All this is to be deplored, especially as there is no valid reason why girls should not reach a degree of proficiency in science comparable to that attained by boys.

The great difference between the attitude of Irish and British schools to science is to be explained by the difference in industrial conditions. Britain, heavily industrialized, is only with difficulty able to meet the demand for scientists, whereas in Ireland industry is not so insistent and the supply usually exceods the demand. This has its repercussions in Irish schools, where the arts subjects tend to dominate the curriculum. Now, modern science, apart from its being a major force in world affairs, has a very definite and unique cultural value, for it discovers in an ever-increasing measure the beauty of form and function that abounds in Nature which itself is the handiwork of the Creator. If the study of the arts-the mere artefacts of man-is cultural, how much more so the study of Nature itself. Science has a very definite and irrefutable claim to be taught even for its own sake and in all schools, for it forms an essential part of a liberal education. A person who knows nothing about science must be regarded as only partially educated. In Ireland specialization at school level is not envisaged, hence it follows that the exclusive study of physics and chemistry as the only science subjects at this level is unsound in principle, since it narrows down the outlook of the young mind. Biology must form an integral part of every school science course. To neglect biology is to neglect at least one half of natural phenomena. In Ireland, where the basic industry is agriculture, the teaching of biology becomes a national necessity.

In Ireland there is a scarcity of science teachers owing to the absorption of science graduates by industry. This could be remedied by asking the teaching priests, nuns and brothers to take up science teaching in greater numbers.

The first of the juvenile lectures was given by Mr. John D. Gallivan, of the sixth form at Newbridge College. He read a very interesting paper, illustrated by lantern slides, on "The Reverend Dr. Callan of Maynooth, pioneer of electrical research". Callan was born in Co. Louth about 1799 and spent the greater part of his life in St. Patrick's College, Maynooth, where he held the chair of natural philosophy from 1826 until his death early in 1864. Attracted by the researches of Faraday and Sturgeon, he built a giant horse-shoe magnet, some $7 \mathrm{ft}$. high and weighing $210 \mathrm{lb}$. When supplied with current from his battery, this magnet could lift two hundred times its own weight. Before 1836, Callan had investigated the principle of the electric motor and had built three. In the earlier forms, he employed a wheel having horizontal soft-iron bars attached to its rim. This was made to rotate by an intermittently energized electromagnet placed under it, the interruptions of current being made by the rotating wheel. A later model using forty electromagnets was able "to 